Five wells have now been drilled and, as stated, all were dry holes. Two of these, Kangâmiut 1 and Ikermiut 1 had indications of gas. Even if the area contains thick sections of sedimentary rocks and even if there are a number of large structures which look promising on a seismic map, none of the wells to date have encountered the necessary combination of suitable source rocks and reservoir rocks, which are two fundamental preconditions for the presence of hydrocarbons in commercial quantities.

These five wells have provided a large number of samples and a wealth of new data. Almost $15000 \mathrm{~m}$ of hole has been drilled below the sea floor, logged and thoroughly sampled. GGU has received nearly 6000 samples of various types. Micropalaeontological and palynological studies are still in progress aimed at establishing the chronostratigraphy in the individual wells and the correlation between these, and with a view to providing information on the depositional environment. Geochemical studies of the organic content of the sediments are still in progress. As these results become available, the regional geology based on seismic interpretation has to be reexamined to see whether more promising prospects can be found.

However, it should be emphasised that the vital question is not whether there are petroleum occurrences in this region, but whether there are commercially exploitable occurrences. This is a high cost frontier region where the costs of extraction would make only the largest petroleum reservoirs commercially viable. The five dry wells to date have not improved the chances for there being such reservoirs in this region.

\title{
References
}

Henderson, G. 1976: Petroleum geology. In Escher, A. \& Watt, W. S. (edit.) Geology of Greenland, 488-505. Copenhagen: Geol. Surv. Greenland.

Schiener, E. J. 1976: Study of organic matter in Cretaceous-Tertiary sediments, central West Greenland. Rapp. Grønlands geol. Unders. 80, 43-49.

\section{Field work on the Precambrian of the Agto - Nordre Strømfjord area, central West Greenland}

\section{John A. Korstgård and Niels Ø. Olesen}

This was the penultimate season of the mapping programme initiated in 1975 with the aim of completing the Agto 1:100 000 map sheet (Olesen \& Sørensen, 1976).

In addition to the present writers the following students from Aarhus University participated in the mapping work: Flemming G. Christiansen, Flemming C. Mengel, Terkel S. Olsen, and Anders Rehkopff, assisted by Karen Marie P. Nielsen and Peter J. Jørgensen.

Support was provided by GGU motor boat Kornerup, skipper Absalon Jensen, and helicopter transport was shared with the GGU geophysical group working out of Søndre Strømfjord (see Secher \& Larsen; Thorning et al., this report). 
Fig. 13. Sketch map of the Agto map sheet. Areas mapped in 1977 are cross-hatched, ruled areas show previous years mapping, while blank areas remain to be mapped in 1978. L denotes lamprophyre-kimberlite locality.

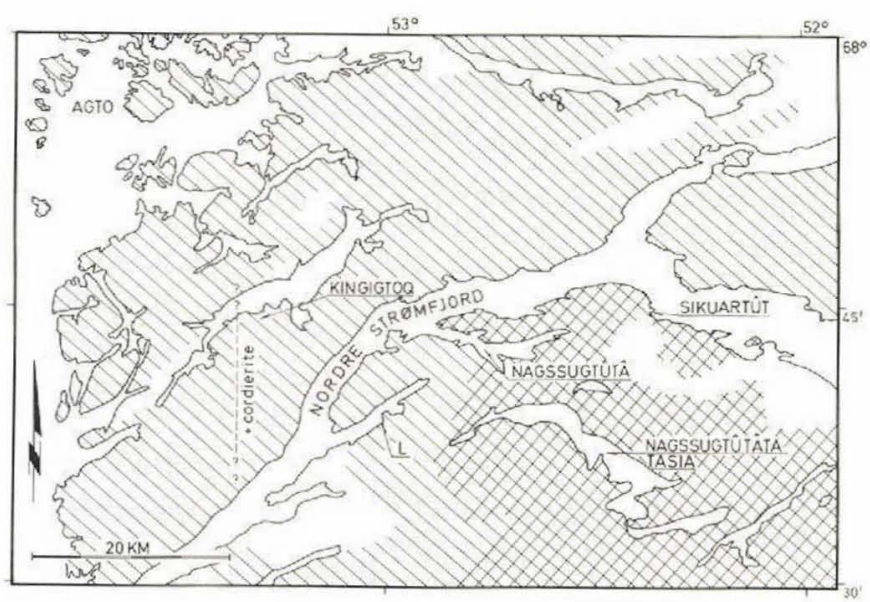

F. G. C. and A. R. completed mapping initiated in 1976 in the Nagssugtûtâ area, and carried out intensive sampling of the metasedimentary units around Nagssugtûtâ for geochemical studies of their petrogenesis; F. C. M. and T. S. O. mapped the south-eastern corner of the map sheet and J. A. K. and N. Ø. O. mapped west and north-east of Nagssugtûtâta tasia. J. A. K. made a preliminary sampling of various rock types for isotopic age dating to be carried out by M. Hickman, Miami University, Ohio. The summer's mapping progress and the distribution of the areas remaining to be studied in the final field season are shown in fig. 13.

\section{Lithology}

The Precambrian rock types can be divided into three main groups; gneisses (hypersthene-biotite gneiss, biotite gneiss, biotite-garnet gneiss), basic (amphibolite, marbles, calcsilicate), ultramafic rocks and discordant dykes (lamprophyres, pegmatites, etc.). Variations in lithology across the map sheet are remarkably small and for a standard description of the various rock types reference can be made to Winter (1974).

A thin layered, cordierite-bearing quartzite was found at several localities between Nagssugtûtâ and Sikuartût. Ramberg (1949) first reported the presence of cordierite in Nordre Strømfjord, but he did not specify where it was found. The cordierite is pale blue, porphyroblastic, occasionally up to $10 \mathrm{~cm}$, but mostly in millimetre or centimetre size. It is commonly associated with garnet in the quartzites and at a few localities cordierite was also observed in garnet-sillimanite-biotite gneisses.

Quartzites and garnet-sillimanite-biotite gneisses are also common in the western, coastal parts of the area, but in these areas cordierite is only found south of Kingigtoq. A tentative cordierite-isograd may therefore be drawn (fig. 13).

Several clearly discordant meta-dolerites were observed in hypersthene gneisses around Nagssugtûtâ. At present these cannot be correlated with either the Kangâmiut meta-dolerites south of Holsteinsborg or the Agto meta-dolerites.

South-west of Nagssugtûtâ three undeformed, cross-cutting dykes of kimberlitic-lamprophyric affinity were observed (fig. 13). They reach a maximum width of $30 \mathrm{~cm}$. 


\title{
Structure
}

The structural pattern of the Agto map sheet is dominated by the typical Nagssugtogidian ENE trend and is most clearly shown by the Nordre Strømfjord shear zone (Bak et al., 1975).

The region south of the Nordre Strømfjord shear zone is characterised by an alternating pattern of linear belts and areas dominated by dome and basin structures with highly variable axial directions.

The rocks of the linear belts show strong planar and linear fabrics defined by preferred shape-orientation of hornblende, orthopyroxene, biotite and graphite, and preferred lattice-orientation of quartz and plagioclase, a subject presently under study.

Some of these southern linear belts may be older than the Nordre Strømfjord shear zone as they are either developed along the limbs of the dome and basin structures and die out along the strike, or they are directly folded into these structures, which are in turn deformed by the Nordre Strømfjord shear zone.

\section{References}

Bak, J., Korstgård, J. \& Sørensen, K. 1975: A major shear zone within the Nagssugtoqidian of West Greenland. Tectonophysics 27, 191-209.

Olesen, N. Ø. \& Sørensen, K. 1976: Studies of the Precambrian basement in the Agto - Nordre Strømfjord area, central West Greenland. Rapp. Grønlands geol. Unders. 80, 68-69.

Ramberg, H. 1949: On the petrogenesis of the gneiss complexes between Sukkertoppen and Christianshaab, W-Greenland. Preliminary report. Meddr dansk geol. Foren. 11, 312-327.

Winter, J. 1974: The Precambrian geology of the Túngarnit nunât area, outer Nordre Strømfjord, central West Greenland. Rapp. Grønlands geol. Unders. 61, 17 pp.

Laboratoriet for Endogen Geologi, Geologisk Institut, Aarhus University, Ole Worms Alle, 8000 Aarhus $C$, Denmark.

\section{Geophysical field work on selected aeromagnetic anomalies in central West Greenland}

\author{
Leif Thorning, Lars Beksgaard Jensen, Christian Marcussen, \\ Birgitte Susanne Mielby and Steen A. Petersen
}

During the airborne operations carried out in 1975 and 1976 (Thorning, 1976, 1977), limited field activity was undertaken on the ground, mainly with the purpose of obtaining measurements of magnetic susceptibility of rocks. In 1977 no airborne operations were carried out and the summer's field work was concentrated on ground surveys. 